SJîñn Jurnal

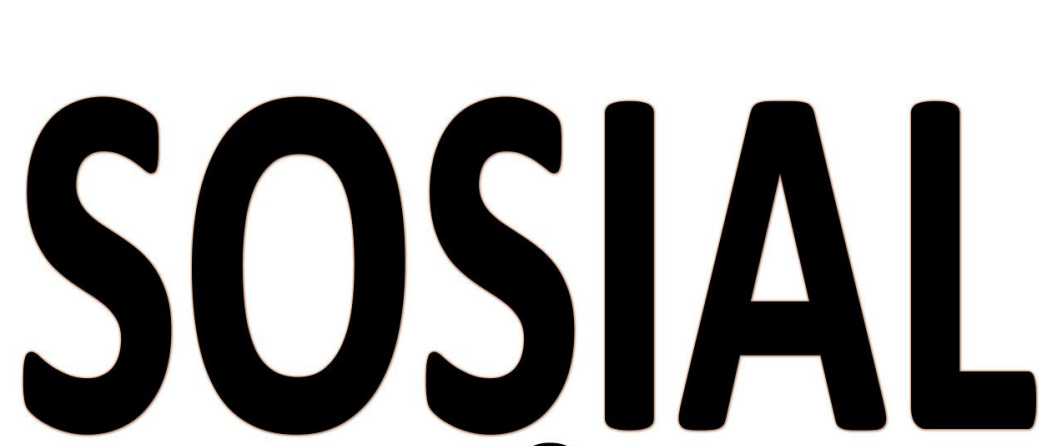

P-ISSN: 2356-1459 E-ISSN: 2654-9050 Vol. 7 No. 5 (2020)
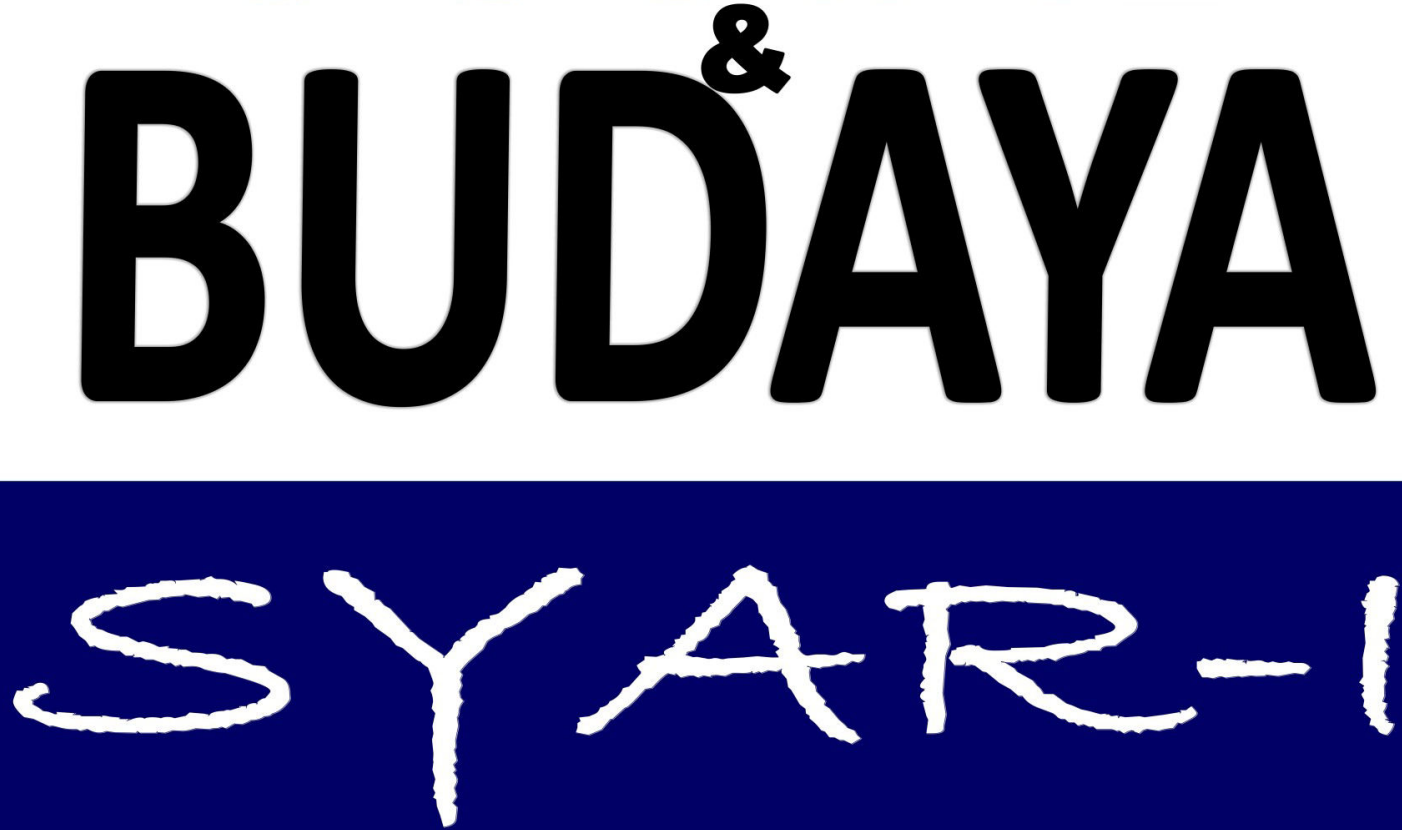

Dampak Covid-19 pada Pendidikan di Indonesia: Sekolah, Keterampilan, dan Proses Pembelajaran Rizqon Halal Syah Aji

Peran Preventif Pemimpin Dalam Pencegahan Penyebaran COVID-19; Strategi Syaykh Al-Zaytun Di Ma'had Al-Zaytun dan Kontribusinya Terhadap Masyarakat Sekitar Imam Prawoto, Siti Ngainnur Rohmah, Fitri Rachmiati Sunarya

Dari Jabariyah, ke Qadariyah, hingga Islam Progresif: Respons Muslim atas Pandemi COVID-19 di Indonesia Nur Hidayah

Transparansi Kebijakan Publik Sebagai Strategi Nasional Dalam Menanggulangi Pandemi Covid-19 Afni Regita Cahyani Muis

Peran Majelis Ulama Indonesia Dalam Mitigasi Pandemi Covid-19;

(Tinjauan Tindakan Sosial dan Dominasi Kekuasaan Max Weber)

Muhamad Agus Mushodiq, Ali Imron

Optimalisasi Upaya Pemerintah Dalam Mengatasi Pandemi Covid 19 Sebagai Bentuk Pemenuhan Hak Warga Negara

Bima Jati, Gilang Rizki Aji Putra

Pandangan Keagamaan Majelis Ulama Indonesia Kabupaten Bogor Terkait Kewajlban Menjaga Diri, Pelaksanaan Shalat Jumat dan Pengurusan Mayit Dalam Situasi Darurat Penyebaran Covid-19 Ahmad Mukri Aji 


\title{
Optimalisasi Upaya Pemerintah Dalam Mengatasi Pandemi Covid 19 Sebagai Bentuk Pemenuhan Hak Warga Negara*
}

\author{
Bima Jati, ${ }^{1}$ Gilang Rizki Aji Putra ${ }^{2}$ \\ ${ }^{1}$ Universitas Islam Negeri Sunan Gunung Jati, Bandung, \\ ${ }^{2}$ Universitas Islam Negeri Syarif Hidayatullah Jakarta
}

$\underline{10.15408 / \text { sjsbs.v7i5.15316 }}$

\begin{abstract}
:
Covid-19 or corona virus is a pandemic that is being felt by almost all countries in the world. The impact is not only on the safety aspects of people's lives, but can also be felt on the political economy aspects, especially in third world countries like Indonesia. Not a few efforts made by the central government to date, but have not provided the effectiveness as it should. So it has the potential to erode public trust on government performance. The purpose of this paper is to describe the alternatives that the government needs to try to maintain the stability of national and state life. Thus the writer uses Polivocalistic research through a case approach, comparative, historical and critical approach. Therefore, the authors come up with alternatives such as; growing collective awareness, creating state economic stability, developing science and technology and perfecting Indonesia's independence.
\end{abstract}

Keywords: Humanity, Third World Country, Citizens' Rights.

\begin{abstract}
Abstrak:
Covid-19 atau virus corona merupakan pandemi yang sedang dirasakan dampaknya oleh hampir seluruh Negara yang ada di Dunia. Dampak tersebut tidak hanya pada aspek keselamatan hidup masyarakat, melainkan dapat dirasakan pada aspek ekonomi politik terutama pada negara dunia ke tiga seperti Indonesia. Tidak sedikit upaya yang dilakukan oleh pemerintah pusat sampai hari ini namun belum memberikan efektivitas sebagaimana mestinya. Sehingga sangat berpotensi merugikan kepercayaan masyarakat (Trust Public) terhadap kinerja pemerintah. Tujuan dari penulisan ini adalah untuk memaparkan alternatif-alternatif yang perlu pemerintah coba lakukan untuk menjaga stabilitas kehidupan berbangsa dan bernegara. Dengan demikian penulis memakai metode penelitian kualitatif dengan pendekatan kepustakaan, historis, dan kritis. Oleh karena itu penulis menggagas alternatif-alternatif seperti : menumbuhkan kesatuan kolektif menciptakan stabilitas ekonomi negara mengembangkan ilmu pengetahuan dan teknologi serta menyempurnakan kemerdekaan Indonesia.
\end{abstract}

Kata kunci : Kemanusian, Negara Dunia Ketiga, Hak Warga Negara.

\footnotetext{
* Diterima: 11 Maret 2020, Revisi: 20 Maret 2020, Diterbitkan 17 Mei 2020.

${ }^{1}$ Bima Jati adalah Mahasiswa Universitas Islam Negeri Sunan Gunung Jati, Bandung. E-mail: bimojati220497@gmail.com

${ }^{2}$ Gilang Rizki Aji Putra adalah Mahasiswa Universitas Islam Negeri Syarif Hidayatullah Jakarta. E-mail: gilang.rizkiajiputra19@mhs.uinjkt.ac.id
} 


\section{Pendahuluan:}

Hari ini dunia sedang dihebohkan oleh sebuah pandemi bernama Covid-19, yaitu sebuah virus mematikan yang memiliki tingkat penularan tinggi. Berbagai upaya telah dilakukan pemerintah dari berbagai negara yang terkena dampak darinya, mulai dari kebijakan lockdown sampai tes masal. Dilansir dari Kompas.com ${ }^{3}$ yang menyatakan bahwa Covid-19 ini bukanlah hasil dari rekayasa genetika, melainkan sebuah epidemi alami yang ditularkan oleh musang, unta, kelelawar, dsb.

Sejatinya virus merupakan sebuah mikroorganisme, yaitu organisme kecil yang hanya mampu dilihat melalui media mikroskopik. Sebagai sebuah makhluk hidup, virus pun tentu mampu melakukan evolusi sebagaimana makhluk hidup yang lain. Namun dalam sejarah evolusi, makhluk hidup nyaris tidak pernah melakukan evolusi kecuali ketika ia dihadapkan dengan kondisi tertentu yang mengharuskannya untuk berevolusi. ${ }^{4}$ Mengingat sebelum menjangkit kepada manusia, virus Covid-19 hanya berinangkan pada hewan seperti kelelawar, trenggiling, dan sebagainya.

Dalam hal ini, manusia selaku satu-satunya hewan yang diciptakan dengan akal, kehendak bebas, dan segala kesempurnaannya harus mampu mempertanggungjawabkan apa yang telah terjadi, karena bukan tidak mungkin kondisi yang mengakibatkan evolusi pada organisme-organisme lain diluar manusia, bahkan manusia lain disebabkan oleh segelintir manusia pula. Bahkan tidak sedikit perubahan yang diprakarsai oleh manusia berdampak pada munculnya stres sosial yang juga tidak sedikit dialami oleh manusia di berbagai penjuru dunia hari ini terkhusus bagi negaranegara terdampak virus corona ini. ${ }^{5}$

Oleh karena itu, penulis mengajukan bentuk-bentuk upaya yang harus dilakukan pemerintah dalam menangani pandemi corona ini, dengan judul "Optimalisasi Upaya Pemerintah Dalam Mengatasi Pandemi Covid 19 Sebagai Bentuk Pemenuhan Hak Warga Negara". Dari pembahasan diatas, penulis mengajukan pertanyaan penelitian yaitu; Mengapa bahaya dari pandemi ini tidak hanya dalam hal kesehatan dan keselamatan hidup? Bagaimana upaya efektif dan solutif yang mampu bahkan harus dilakukan oleh pemerintah untuk meminimalisir dampak tersebut.

\section{Kemanusiaan}

Persoalan kemanusiaan selalu menjadi titik fokus utama dari setiap permasalahan yang terjadi di dunia dewasa ini. ${ }^{6}$ Menurut perjalanan sejarahnya, dominasi manusia diatas manusia lain selalu terjadi dalam setiap periode kesejarahan peradaban manusia dalam bentuk yang variatif. Bahkan tidak sedikit dijumpai penindasan-penindasan yang dilakukan oleh manusia terhadap manusia lain dengan

${ }^{3}$ Holy Kartika, "Bukan Rekayasa Genetika, Studi Menguak Asal-Usul Virus Corona”, diakses dari https://www.kompas.com/sains/read/2020/03/18/193100223/bukan-rekayasa-genetika-studi-menguak-asalusul-virus-corona, pada tanggal 20 Maret 2020 pukul 13.00.

${ }^{4}$ https://id.m.wikipedia.org/wiki/Evolusi

${ }^{5}$ Jalaluddin Rakhmat, Rekayasa Sosial, Bandung: Remaja Rosdakarya, 2005, hlm. 32.

${ }^{6}$ Ali Shatiati, Paradigma Kaum Tertintas, Yogyakarta, Ananda, 2001, hlm 61 
mengatasnamakan agama. Sebagaimana terjadi di benua Eropa pada zaman Renaissance pada kurun waktu sekitar abad 15-16 masehi dengan tokoh seperti Nicolas Copernicus (1473-1543), Johanes Kepler (1571-1630), Galileo Galilei (1564-1643), Rene Descartes (1596-1650)

Perjuangan utama yang mereka lakukan berupa pembebasan manusia dari kekangan gereja terutama kekangan terhadap perspektif manusia. Dengan penelitian empiris, serta rasionalisme yang mereka bawa, Eropa mampu melewati Abad Kegelapan dengan cukup cemerlang, salah satu tanda kecemerlangan itu berupa lahirnya sains. Seiring berjalannya waktu, perkembangan sains tersebut pun kembali memberikan dampak negatif bagi kemanusiaan, terutama ketika masa Perang Dunia 1 dan 2. Proses dehumanisasi yang terjadi kala itu sejatinya tidak hanya berupa "penumbalan" manusia sebagai syarat tercapainya tujuan politik dengan perang. Melainkan telah terjadi pada masa produksi senjata, penguatan kekuatan militer, dsb. Hal ini disebabkan karena tidak adanya keseimbangan antara produksi dan distribusi pada industri dunia kala itu. ${ }^{8}$ Mirisnya dampak-dampak negatif dari ketidakseimbangan demikian pun dirasakan oleh negara-negara yang tidak terlibat langsung dalam perang tersebut, tidak terkecuali Indonesia yang tergolong di negara Non-blok kala itu.

\section{Negara Dunia Ketiga}

Istilah "Dunia Ketiga" muncul pada masa Perang Dingin untuk menyebut negara-negara yang tidak memihak dengan NATO atau Blok Komunis. Amerika Serikat, Kanada, Jepang, Korea Selatan, Eropa Barat dan sekutunya mewakili Dunia Pertama, sedangkan Uni Soviet, Tiongkok, Kuba, dan sekutunya mewakili Dunia Kedua. Istilah ini memungkinkan negara-negara di dunia dibagi menjadi tiga kelompok berdasarkan politik dan ekonominya. ${ }^{9}$ Lebih lanjut Arief Budiman mengatakan bahwa negara dunia ketiga merupakan negara yang tergolong miskin dalam hal ekonominya. ${ }^{10}$ Sejatinya negara dunia ketiga pun merupakan negara yang dapat dikatakan negara yang memiliki ketergantungan ekonomi kepada negara-negara yang lebih dahulu mumpuni. Indonesia merupakan salah satu negara yang dapat dikategorikan ke dalam negara dunia ketiga karena keterlibatannya pada gerakan non-blok, serta ketidakstabilan ekonominya.

Mirisnya pada era yang serba modern seperti sekarang ini negara dunia ketiga hanya terlihat dijadikan pasar atas surplus produksi negara-negara maju. Bukan tidak mungkin bagi negara dunia ketiga terkhusus Indonesia yang sangat kaya akan segala potensi alam maupun manusia yang dimilikinya mampu bersaing di pasar ekonomi internasional dengan negara-negara maju, apabila proses kesejarahan yang telah lebih dahulu dilalui oleh mereka mampu dilalui pula oleh Indonesia dengan segala

\footnotetext{
${ }^{7}$ Ahmad Tafsir, Filsafat Umum, Bandung, Remaja Rosdakarya, 2015, hlm 126

8 Tan Malaka, Thesis, Yogyakarta, Octopus, 2014, hlm 24

${ }_{9}$ https://id.m.wikipedia.org/wiki/Dunia_Ketiga

${ }^{10}$ Arief Budiman, Teori Pembangunan Dunia Ketiga, Jakarta, Gramedia, 2000, hlm 9
} 
pertimbangan dengan konteks realita yang sedang terjadi serta tantangan yang akan datang.

\section{Hak Warga Negara}

Ketentuan utama di Indonesia yang mengatur tentang hak-hak warga negara adalah Undang-Undang Dasar Negara Republik Indonesia Tahun 1945 (UUD NRI 1945). Selain memiliki absoluditas dari segi formilnya, sejatinya ketentuan tersebut pun sangat matang dari segi teoritisnya, karena secara garis besar tidak bertentangan dengan nilainilai kemanusiaan. Adapun nilai-nilai kemanusiaan yang penulis maksud antara lain berupa; a. Hak untuk hidup, b. Hak untuk memperoleh keadilan, c. Hak persamaan, d. Hak kebebasan, e. Hak menyatakan kebenaran, f. Hak mendapatkan perlindungan, g. Hak ekonomi, h. Hak untuk memiliki. ${ }^{11}$

Keseluruhan nilai kemanusiaan tersebut secara implisit maupun eksplisit tidak tertera dalam ketentuan yang diatur oleh konstitusi. Namun dalam realisasinya, pemenuhan hak-hak tersebut masih sangat jauh dari maksimal. Hal ini dibuktikan dengan masih bertumpuknya kasus pelanggaran Hak Asasi Manusia pada masa lalu yang belum terselesaikan sampai hari ini, masih banyaknya rakyat Indonesia yang tidak mendapatkan pendidikan yang layak hanya atas keterbelakangan ekonomi, masih terus dipermasalahkannya angka pengangguran di Indonesia sampai hari ini.

\section{Metode Penelitian}

Jenis Penelitian dalam tulisan ini berupa Penelitian Kualitatif, yaitu analisis data secara induktif dan dikonstruksikan menjadi hipotesis atau bahkan teori. ${ }^{12}$ Adapun pendekatan yang penulis gunakan berupa, pendekatan kepustakaan, historis, polivokalistis ${ }^{13}$ komparatif dan kritis.

\section{Pembahasan}

\section{Modernisasi Sebagai Media Dehumanisasi Global}

Ali Shariati mengatakan bahwa abad 20 merupakan abad kemunduran ideologi serta peradaban manusia, dimana para ilmuwan dan orang-orang yang menitikberatkan netralitas ilmiah menjadi anjing penjaga dan tentara sewaan para korporat dunia. ${ }^{14}$ Sehingga kehidupan manusia hanya sebatas lahan yang sangat potensial di mata mereka dan terus membentuk kelas dibawah sebagai mesin bernyawa dengan memanipulasi pemaknaan "kebutuhan hidup" menjadi sekedar "kebutuhan bertahan hidup." Perlahan tapi pasti manusia mulai kehilangan kesempurnaan jati dirinya sebagai makhluk yang memiliki ruh Tuhan dalam dirinya sebagaimana firman Allah Swt.:

\footnotetext{
${ }^{11}$ Miriam Budiardjo, Dasar-Dasar Ilmu Politik, Jakarta, Gramedia Pustaka Utama, 2008, hlm 240

${ }_{12}$ Beni Ahmad Saebani, Filsafat Ilmu \& Metode Penilitian, Bandung, Pustaka Setia, 2015, hlm 235

${ }^{13}$ Bagong Suyanto, Sosiologi Ekonomi, Jakarta, Kencana, 2017, Kencana, hlm 38

${ }^{14}$ Ali Shariati, Ideologi Kaum Intelektual, Bandung, Mizan, 1993, hlm 107
} 


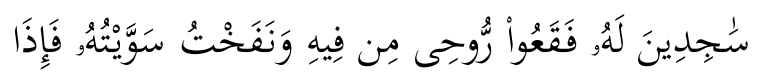

"Maka apabila telah Kusempurnakan kejadiannya dan Kutiupkan kepadanya roh (ciptaan) $\mathrm{Ku}$; maka hendaklah kamu tersungkur dengan bersujud kepadanya" (Q.S Shad 72). ${ }^{15}$

Lebih lanjut Ritzer menyatakan bahwa pada era post-industrialisme sekarang ini, eksploitasi kapitalisme ditujukan kepada pola dan daya konsumsi masyarakat melalui penyebarluasan cengkeraman mereka pada segala aspek kehidupannya, dari mulai makanan, pakaian, hiburan yang oleh Adorno hal demikian dinamakan sebagai sebuah Industrialisasi Budaya. ${ }^{16}$ Dalam aspek kehidupan bernegara pun tidak sedikit bentuk kapitalisasi berupa komersialisasi yang berujung pada proses dehumanisasi, seperti; politik, hukum, bahkan pendidikan.

Mirisnya sebagai negara yang telah cukup lama memperoleh kemerdekaan dari penjajahan imperialisme, Indonesia pun masih belum mampu melepaskan diri dari belenggu kapital dunia sampai hari ini. Sehingga dapat dikatakan bahwa kemerdekaan yang telah diproklamirkan pada 17 Agustus 1945 silam belum lah paripurna. Indonesia juga merupakan sebuah negara besar dan kaya akan sumber daya alam maupun manusia, serta kaya pula akan budaya dan adat-istiadat rakyatnya. Merupakan sebuah tantangan besar yang sangat menjanjikan bagi para kapital untuk mengikisnya, bahkan menggantikannya dengan hal lain yang mereka inginkan.

Pada kenyataannya tidak sedikit budaya bangsa yang telah terkikis oleh berbagai hal yang dikonsumsi masyarakat Indonesia sampai hari ini. Terlebih lagi setelah Covid-19 ini menjadi trend pembahasan di berbagai media, interaksi sosial antara individu satu dengan yang lain semakin berjarak, padahal hal itu pun sejatinya sudah terus diperenggang oleh hadirnya sosial media dengan segala inovasinya. Sehingga munculah perbedaan-perbedaan baru pada masyarakat dalam hal penyikapan sebuah fenoma yang cenderung "dibiaskan."17

Hal sedemikian memang terjadi di era-post-modern seperti sekarang ini, namun sejatinya hal itu bukanlah bagian dari modernisasi yang sesungguhnya. Melainkan sebuah proses westernisasi dimana masyarakat dibentuk untuk hidup tanpa pondasi spiritualitas dan moralitas yang kokoh berdasarkan keimanan kepada Tuhan Yang Maha Esa. ${ }^{18}$ Fenomena Covid-19 ini pun tidak sedikit mengikis nilai-nilai sosial pada masyarakat sebagai makhluk sosial.

Munculnya sistem lockdown dan social distancing merupakan reaksi sekaligus upaya pemerintah dalam mengatasi pandemi ini. Disisi lain hal sedemikian merupakan bentuk lain dari proses dehumanisasi, walaupun langkah tersebut ditujukan untuk meminimalisir penyebaran virus dengan efektivitas cukup tinggi, namun ia pun berpotensi mendorong masyarakat beranggapan bahwa semua manusia adalah inang

${ }^{15}$ https://tafsirweb.com/8558-quran-surat-shad-ayat-72.html

${ }_{16}$ Bagong Suyanto, Sosiologi Ekonomi, Jakarta, Kencana, 2017, hlm 23

17 Haidar Bagir, Islam tuhan Islam Manusia, Jakarta, Mizan, 2017, hlm. 77.

${ }^{18}$ Nurcholis Madjid, Islam, Doktrin dan Peradaban, Jakarta, Paramedina, 1999, hlm 8 
bagi virus ini. Semua orang memang memiliki potensi untuk terjangkit virus corona ini, namun tidak berarti bahwa seluruh manusia adalah inang baginya.

Lambatnya proses identifikasi atas orang yang positif terinfeksi merupakan sebuah gambaran nyata tentang kesiapan dan keseriusan pemerintah dalam menangani bencana ini. Sedangkan potensi terlahirnya sebuah asumsi tak berdasar pada yang disebabkan oleh kebijakan pemerintah, merupakan gambaran atas kualitas intelektualitas serta kepemimpinannya. Terlebih dalam perspektif ekonomi kritis. Hal demikian merupakan sebuah upaya yang cenderung berdampak timbulnya monopolisasi ekonomi oleh penguasa dan orang-orang yang diluar kekuasaannya yang sering disebut sebagai pemilik modal, dengan tujuan menghambat pertumbuhan ekonomi orang-orang yang berada dibawah mereka dengan pola determinasi pondasi ekonomi sebagai infrastruktur sosial atas suprastruktur sosial terutama dalam aspek perkembangan budaya sebagai individu yang bebas. ${ }^{19}$

\section{Upaya Pemerintah Indonesia Dalam Penanganan Covid-19 Sebagai Bentuk Realisasi Hak-Hak Warga Negara}

Dilansir oleh Kumparan.com ${ }^{20}$, sikap yang diambil oleh pemerintah pusat selaku pengampu kebijakan tertinggi di Indonesia adalah melakukan tes masal. Karena ketidakmapanan teknologi yang ada di Indonesia hari ini, mengharuskan pemerintah melakukan impor alat tes tersebut dari China. Belum jelas seberapa banyak alat tes yang diimpor, maupun seberapa banyak uang yang dikeluarkan pemerintah untuk membelinya, setidaknya usaha yang demikian merupakan bentuk pertanggungjawaban yang cukup layak diberikan apresiasi untuk sementara waktu. Selama upaya tes masal tersebut tidak terbungkuskan upaya komersialisasi dan memperjauh jarak antara si kaya dan si miskin, sebagaimana yang telah terjadi di negara ini dalam aspek politik, budaya, gaya hidup, bahkan pendidikan. Sebesar apapun dampak yang berpotensi timbul akibat pandemi ini, pada dasarnya tetap saja Covid-19 tidak bisa dinyatakan bersalah. Dalam hal ini pemerintah harus mampu bertanggungjawab dan memenuhi hak rakyat selaku warga negara terutama sebagaimana yang telah diatur dalam UUD 1945, dan rakyat pun harus mampu bertanggung jawab selaku manusia yang berakal.

Masyarakat Indonesia tentu semakin resah akibat pandemi Covid-19, karena mengancam kesehatan dan keberlangsungan hidupnya. Sebagai negara hukum yang menjunjung tinggi keadilan atas dasar hukum, sudah barang tentu pemerintah selaku penyelenggara keberlangsungan hidup bernegara melaksanakan dengan menjunjung tinggi aturan-aturan hukum yang berlaku. Konstitusi negara Republik Indonesia banyak mengatur tentang hak-hak warga negara, yang sejatinya sampai hari ini pun belum mampu terwujudkan secara sempurna dalam implementasinya. UndangUndang Dasar Negara Republik Indonesia 1945 pasal 27 ayat 2 dengan tegas menyatakan bahwa setiap warga negara berhak atas pekerjaan dan penghidupan yang

\footnotetext{
${ }^{19}$ Andi Muawiyah Ramly, Peta Pemikiran Karl Marx, Yogyakarta, LKIS, 2013, hlm. 154.

${ }^{20}$ https://money.kompas.com/read/2020/03/18/132707426/erick-thohir-pesan-5000000-alat-tesvirus-corona?page=all
} 
layak untuk kemanusiaan. Dalam hal distribusi sumber daya manusia seperti pemberian lapangan pekerjaan pun pemerintah belum mampu mewujudkannya. Hal ini dibuktikan dengan hadirnya sebuah inovasi konyol berupa Kartu Prakerja yang mereka prakarsai tempo hari. ${ }^{21}$ Terlebih dalam konteks fenomena global yang sangat insidental kali ini, kemungkinan masyarakat akan kehilangan hak fundamental berupa hak untuk hidup sejatinya sangat besar. Mengingat dalam mengatasi masalah pengangguran yang terus diperbincangkan dari setiap periode kepemimpinan saja belum mampu terealisasikan secara utuh, apalagi penanganan insiden yang bersifat tidak terduga seperti fenomena covid 19 ini. Hemat penulis, upaya-upaya pemerintah dalam mengentaskan masalah kehidupan berbangsa dan negara hanya terlihat sebatas pemenuhan prosedur formal semata, karena nyatanya upaya tersebut tidak memberikan dampak yang signifikan. Hal ini tentu akan melahirkan rasa pesimistis di masyarakat dengan anggapan bahwa hanya kehendak Tuhan yang mampu melepaskan Indonesia dari belenggu keterpurukan. Anggapan sedemikian serupa dengan Anarkisme Ilmiah yang pernah dicetuskan oleh Ali Shariati, yaitu rasa pesimistis terhadap filsafat sosial dan humaniora serta menganggap bahwa segala sesuatu yang terjadi hanya berdasarkan sebuah kebetulan semata. ${ }^{22}$

Oleh karena itu penulis mencoba menjabarkan upaya-upaya radiks yang harus dilakukan pemerintah dalam penanganan pandemi ini selain upaya tes masal, lockdown, dan social distancing yang telah mereka gencarkan, antara lain;

\section{Menumbuhkan kesadaran masyarakat untuk hidup dengan gaya hidup yang sehat.}

Mengingat bahwa pencegahan pertumbuhan serta penyebarluasan virus corona sampai hari ini belum bisa dibatasi. Bahkan proses identifikasi untuk memperoleh validitas data pun belum selesai dilakukan oleh pemerintah yang baru akan mendatangkan alat tes beserta obat-obatannya.

Penetapan kebijakan lockdown atau social distancing memang akan menghambat perkembangan virus sementara, namun cenderung akan membawa dampak lebih signifikan terkhusus pada stabilitas ekonomi negara yang tidak bisa dipungkiri sedang berada dalam posisi terombang-ambing. Oleh karena itu penumbuhan kesadaran kolektif pada masyarakat, merupakan langkah yang dirasa cukup tepat sebagai bentuk antisipasi atas dampak berkelanjutan dari pandemi ini. Walaupun akan jauh lebih baik apabila kesadaran kolektif ini tidak dibentuk atas sebuah insiden semata, mengingat hal sedemikian dapat pula berdampak munculnya stres sosial pada masyarakat sebagai mana tertera pada pembahasan sebelumnya.

\footnotetext{
${ }^{21}$ https://www.google.com/amp/s/amp.kompas.com/money/read/2020/03/27/071436826/syaratmendapatkan-kartu-pra-kerja-dan-bisa-terima-gaji-rp-1-juta-per-bulan

${ }^{22}$ Ali Shariati, Paradigma Kaum Tertindas, Yogyakarta, Ananda, 2001, hlm 38
} 


\section{Menciptakan stabilitas ekonomi, agar seluruh elemen masyarakat mampu hidup dengan layak.}

Sepanjang perjalanan sejarah perekonomian Indonesia, negara ini tidak pernah terlepas dari permasalahan ekonomi, terutama dalam hal finansial negara yang bahkan defisitnya secara terang-terangan dan terus menerus dicantumkan dalam Anggaran Pendapatan dan Belanja Negara. ${ }^{23} \mathrm{Hal}$ ini merupakan bentuk pengakuan secara tidak langsung terhadap masyarakat bahwa negara dengan teritorial luas, sumber daya manusia dan alam yang melimpah, bahkan dengan kekayaan budaya seperti Indonesia pun tidak berdaya menghadapi tantangan kompetisi dunia hari ini. Selain itu, hal sedemikian tentu akan berpotensi melahirkan rasa pesimistis pada masyarakat Indonesia terutama masyarakat yang tergolongkan dalam masyarakat proletariat.

\section{Melepaskan cengkeraman-cengkeraman kepentingan di luar kepentingan negara yang proporsional untuk dilepaskan.}

Menurut Engels, kondisi-kondisi politik merupakan aspek penentu situasi ekonomi. ${ }^{24} \mathrm{Hal}$ ini tentu juga tidak dapat dilepaskan begitu saja dari aspek kesejarahan bangsa yang terus mengalami penjajahan dengan berbagai bentuk transformasinya dan belum mampu memerdekakan diri secara utuh.

Tan Malaka pun memberikan sebuah indikator kemerdekaan yang cukup relevan sampai hari ini, beliau menuturkan bahwa kemerdekaan $100 \%$ bukan hanya dicapai melalui revolusi nasional semata, melainkan harus disertai dengan revolusi ekonomi yang bersamaan pula dengan pengambilan tindakan sosial kolektif. Lebih lanjut beliau pun menuturkan bahwa setidaknya prasyarat untuk melakukan revolusi yang sedemikian adalah kekuasaan politik secara utuh dan penguasaan ekonomi sekurang-kurangnya sebanyak $60 \%$ oleh kaum murba. ${ }^{25}$

Oleh karena itu dependensi Indonesia pun harus terus bertransformasi menuju sebuah independensi nasional. Namun ironisnya seiring perjalanan waktu dan perkembangan demokrasi di Indonesia, khususnya pasca Reformasi 98, kehidupan demokrasi di negeri ini lebih terlihat bahkan lebih terasa seperti kamuflase untuk menutupi kapitalisme yang telah menduduki sistem ini.

Dibalik pandemi Covid-19 ini, terdapat sebuah aturan yang akan mengkerdilkan proletar dan memberhalakan para pemilik modal, yaitu RUU Cipta Kerja yang tidak boleh luput dari perhatian kita sebagai bentuk kepedulian terhadap masa depan bangsa. Bahkan Rasulullah SAW pun pernah bersabda dalam sebuah hadits yang diriwayatkan oleh Imam Muslim:26

\footnotetext{
${ }^{23}$ https://www.kemenkeu.go.id/informasi-publik/uu-apbn-dan-nota-keuangan/uu-apbn-dannota-keuangan-2020/

${ }^{24}$ Frederick Engels, Anti Duhring Terjemahan Oey Hay Djoen, Jakarta, Hasta Mitra, 2007, hlm. 195.

25 Tan Malaka, Gerpolek, Yogyakarta: Diandra Pustaka Indonesia, 2012, hlm. 20.

${ }^{26}$ https://www.google.com/amp/s/abuazm.wordpress.com/2011/01/13/al-muminulqowiyyu/amp/
} 


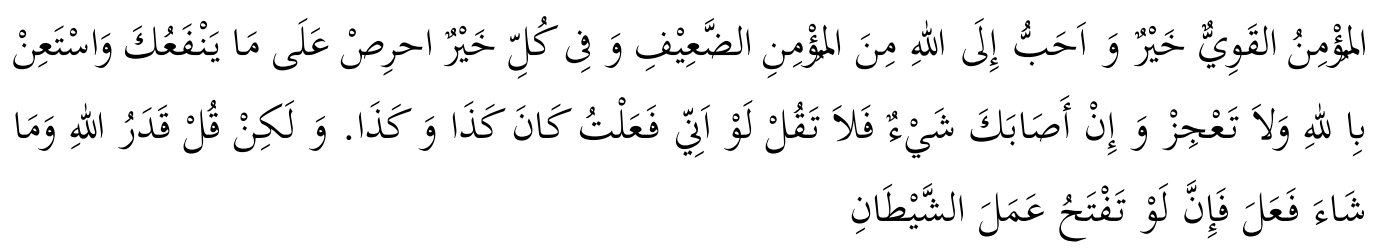

"Mukmin yang kuat lebih baik dan lebih dicintai oleh Allah daripada mukmin yang lemah. Namun, keduanya tetap memiliki kebaikan. Bersemangatlah atas hal-hal yang bermanfaat bagimu. Minta tolonglah pada Allah, jangan engkau lemah. Jika engkau tertimpa suatu musibah, maka janganlah engkau katakan: 'Seandainya aku lakukan demikian dan demikian.' Akan tetapi hendaklah kau katakan: 'Ini sudah jadi takdir Allah. Setiap apa yang telah Dia kehendaki pasti terjadi.' Karena perkataan law (seandainya) dapat membuka pintu syaithon."

Dalam konteks kehidupan di era sekarang ini, kondisi ekonomi merupakan salah satu tolok ukur kekuatan yang paling utama di dunia. Bahkan dalam penentuan status suatu negara dapat dikatakan maju, berkembang atau terbelakang pun salah satu faktor penentunya adalah melalui perhitungan pendapatan perkapita negara tersebut. Lebih daripada itu, kondisi ekonomi masyarakat akan sangat mempengaruhi pola konsumsinya terhadap barang, jasa, bahkan sampai ke produk pemikiran. Tentunya hal demikian akan pula berdampak besar pada mindset tiap-tiap individu dalam masyarakat, yang apabila dengan adanya desakan ekonomi yang dialaminya akan berpotensi mengarahkan individu tersebut ke arah alienasi berupa tuntutan produksi yang hanya untuk memenuhi kebutuhan konsumsinya.

\section{Mengembangkan teknologi yang mampu mendorong kehidupan masyarakat ke arah yang lebih layak.}

Pada umumnya teknologi merupakan sebuah ciri khas peradaban masyarakat barat bahkan sejak Perang Dunia I. Mereka terus gencar mengembangkan teknologi dari mulai persenjataan sampai teknologi produksi barang untuk mempermudah kerja manusia sehari-hari. Dalam sejarahnya, masyarakat barat yang sedang mengembangkan ekonomi kapital kala itu, memang terus dituntut untuk mampu mengembangkan kemampuan produksi mesin-mesin yang ada. Karena dalam prinsipnya, semakin tinggi efektivitas mesin-mesin produksi maka semakin banyak nilai lebih yang mampu dihasilkan. ${ }^{27}$ Dalam konteks Indonesia sebagai negara dunia ketiga yang 'terlambat' sadar akan pentingnya teknologi untuk menghadapi kompetisi global, hal ini tentu merupakan sebuah tantangan yang berat. Karena sejatinya, dampak dari kompetisi mesin-mesin produksi barat kala itu, menghasilkan surplus atau over produksi yang pada akhirnya didistribusikan ke negara-negara dunia ketiga termasuk Indonesia. Anehnya, setelah sekian dekade Indonesia merdeka, perkembangan teknologi di negara ini masih tergolong lambat, apalagi ketika dikomparasikan dengan negara-negara ASEAN, seperti: Singapura, Brunei, dan Malaysia.

${ }^{27}$ Karl Marx, Das Capital, Jakarta, Hasta Mitra, 2004, Edisi ke-4, Buku Pertama, hlm. 389. 


\section{Kesimpulan}

Merupakan sebuah tantangan pula bagi kita untuk mampu memperbaiki kualitas pendidikan dan riset keilmuan yang ada di Indonesia. Terlebih, mengingat bahwa dalam kondisi genting akibat Covid-19 sekarang ini negara masih membutuhkan alat untuk memastikan seseorang terjangkit virus tersebut atau tidak dan malah mengimpor alat tersebut dari negara yang merupakan pusat penyebaran virus mematikan ini pertama kali.

Dalam menghadapi pandemi ini, kaum intelektual di segala kastanya bertugas menjadi aparatur ideologis sesuai dengan keilmuan yang menjadi titik fokusnya, dengan tetap mengacu pada semangat kemanusiaan dan demi kemajuan peradaban bangsa. Adapun pemerintah selaku representasi dari segenap rakyat Indonesia, harus lebih cerdas dalam menentukan kebijakan. Karena dipungkiri atau tidak kondisi seperti sekarang ini merupakan ajang pembuktian diri bagi pemerintah yang sebelumnya kurang memiliki kredibilitas dimata sebagian masyarakat Indonesia akibat kisruhnya Pemilu 2019 lalu. Sebesar keseriusan yang dibuktikan dengan kinerja dan hasil dalam perang melawan pandemi ini, sebesar itu pula kepercayaan yang akan masyarakat berikan untuk membangun sinergitas dengan pemerintah dalam menciptakan tatanan kehidupan berbangsa dan bernegara yang lebih ideal.

\section{Referensi:}

Bagir, Haidar. (2017) Islam Tuhan Islam Manusia, Jakarta, Mizan, hlm. 77.

Buana, Dana Riksa, "Analisis Perilaku Masyarakat Indonesia dalam Menghadapi Pandemi Virus Corona (Covid-19) dan Kiat Menjaga Kesejahteraan Jiwa," Salam: Jurnal Sosial dan Budaya Syar-i, Volume 7, No. 3 (2020).

Budiardjo, Miriam. (2008) Dasar-Dasar Ilmu Politik, Jakarta, Gramedia Pustaka Utama, hlm 240

Budiman, Arief. (2000) Teori Pembangunan Dunia Ketiga, Jakarta, Gramedia, hlm 9

Engels, Frederick. (2007) Anti Duhring Terjemahan Oey Hay Djoen, Jakarta: Hasta Mitra, hlm. 195.

Holy Kartika,“Bukan Rekayasa Genetika, Studi Menguak Asal-Usul Virus Corona”, diakses dari https://www.kompas.com/sains/read/2020/03/18/193100223/bukanrekayasa-genetika-studi-menguak-asal-usul-virus-corona, pada tanggal 20 Maret 2020 pukul 13.00.

https://id.m.wikipedia.org/wiki/Dunia Ketiga

https://id.m.wikipedia.org/wiki/Evolusi

https://money.kompas.com/read/2020/03/18/132707426/erick-thohir-pesan-5000000alat-tes-virus-corona?page=all

https://tafsirweb.com/8558-quran-surat-shad-ayat-72.html 
https://www.google.com/amp/s/abuazm.wordpress.com/2011/01/13/al-muminulqowiyyu/amp/

https://www.google.com/amp/s/amp.kompas.com/money/read/2020/03/27/071436826/s yarat-mendapatkan-kartu-pra-kerja-dan-bisa-terima-gaji-rp-1-juta-per-bulan

https://www.kemenkeu.go.id/informasi-publik/uu-apbn-dan-nota-keuangan/uu-apbndan-nota-keuangan-2020/

Madjid, Nurcholis. (1999) Islam Doktrin dan Peradaban, Jakarta, Paramedina, hlm 8

Maggalatung, A.S.; Aji, A.M.; Yunus, N.R. How The Law Works, Jakarta: Jurisprudence Institute, 2014.

Malaka, Tan. (2012) Gerpolek, Yogyakarta: Diandra Pustaka Indonesia, hlm. 20.

Malaka, Tan. (2014) Thesis, Yogyakarta, Octopus, hlm 24

Marx, Karl. (2004) Das Capital. Jakarta: Hasta Mitra, Edisi ke-4, Buku Pertama, hlm. 389.

Rakhmat, Jalaluddin. (2005), Rekayasa Sosial, Bandung: Remaja Rosdakarya, hlm. 32.

Ramly, A. M. (2013) Peta Pemikiran Karl Marx, Yogyakarta: LKIS, hlm. 154.

Rezki, Annissa; Anggraeni, RR. Dewi; Yunus, Nur Rohim. "Application of Civil Law Theory In the Termination of Custody of Adopted Children in Indonesia," Journal of Legal Research, Volume 1, No. 6 (2019).

Rohmah, S.N. "Adakah Peluang Bisnis di Tengah Kelesuan Perekonomian Akibat Pandemi Corona?," Adalah: Volume. 4, No. 1 (2020).

Saebani, B A. (2015) Filsafat Ilmu \& Metode Penilitian, Bandung, Pustaka Setia, hlm 235

Shariati, Ali. (1993) Idiologi Kaum Intelektual, Jakarta: Mizan, Hlm 107

Shariati, Ali. (2001) Paradigma Kaum Tertindas, Yogyakarta, Ananda, hlm 38

Shatiati, Ali. (2001) Paradigma Kaum Tertintas, Yogyakarta, Ananda, hlm 61

Suyanto, Bagong. (2017) Sosiologi Ekonomi, Jakarta, Kencana, hlm 38

Suyanto, Bagong. (2017) Sosiologi Ekonomi, Jakarta, Kencana, hlm 23

Tafsir, Ahmad. (2015) Filsafat Umum, Bandung, Remaja Rosdakarya, hlm 126

Yunus, N.R.; Rezki, Annissa. "Kebijakan Pemberlakuan Lock Down Sebagai Antisipasi Penyebaran Corona Virus Covid-19," Salam: Jurnal Sosial dan Budaya Syar-i, Volume 7, No. 3 (2020). 
Bima Jati, Gilang Rizki Aji Putra

484 - Fakultas Syariah dan Hukum UIN Syarif Hidayatullah Jakarta 


\section{Indexed by :}
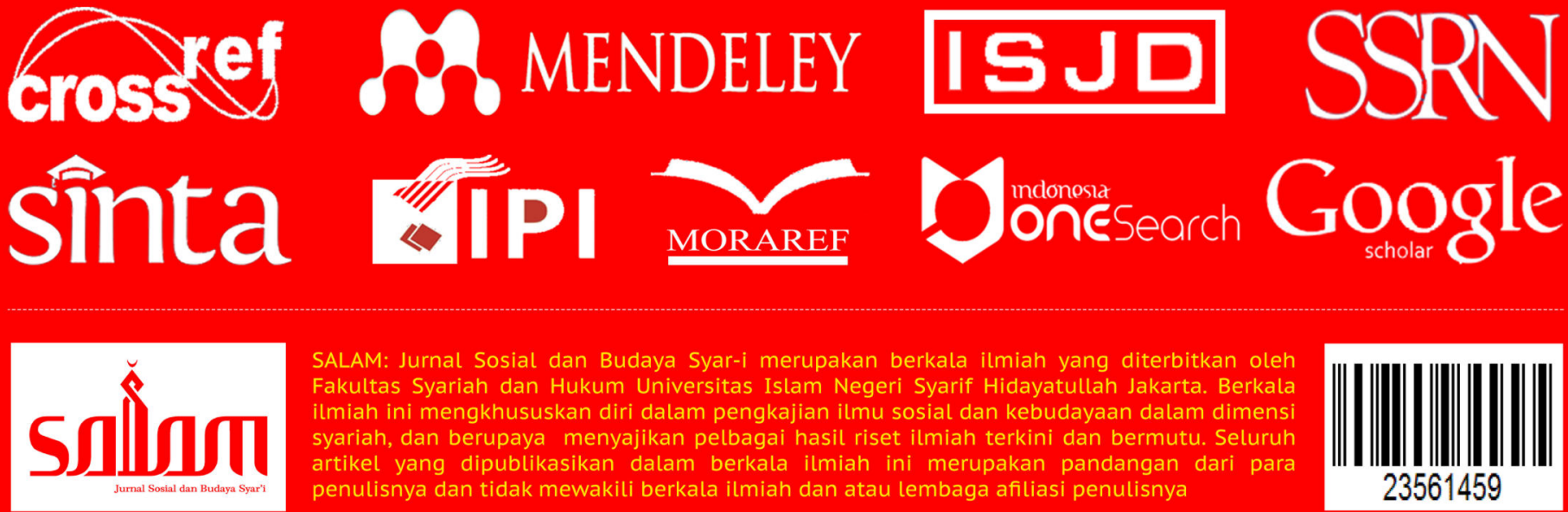

SALAM: Jurnal Sosial dan Budaya Syar-i merupakan berkala ilmiah yang diterbitkan oleh Fakultas Syariah dan Hukum Universitas Islam Negeri Syarif Hidayatullah Jakarta. Berkala ilmiah ini mengkhususkan diri dalam pengkajian ilmu sosial dan kebudayaan dalam dimensi syariah, dan berupaya menyajikan pelbagai hasil riset ilmiah terkini dan bermutu. Seluruh artikel yang dipublikasikan dalam berkala ilmiah ini merupakan pandangan dari para penulisnya dan tidak mewakili berkala ilmiah dan atau lembaga afiliasi penulisnya

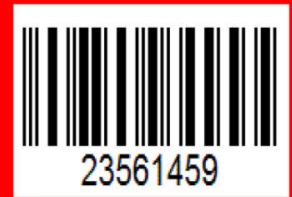

